\title{
"There Are Sermons In Stones"
}

\author{
By ALLAN J. HUDSON, Mortlach
}

Much travelling in Southern Saskatchewan last summer has begotten pleasant memories - some unforgetable. The courtesy and helpfulness of people, the kindness of friends, in retrospect, warm the heart.

On a perfect morning late in July, standing on a low ridge separating a well-filled Lake Johnston from the alkali lake at Bishopric to the east, the heavenly blue expanse reached to the blue horizon in the west. The raised beaches in both lakes leads one to believe that they were originally one.

Incidentally, to mar the picture, there seems to be something lethal for ducks about Lake Johnston water. Full as the lake was last summer, there were dead ducks along the shore in August. It seems to be especially deadly in the fall and in dry seasons.

If Lake Johnston, that morning, left the impression of great beauty, the gleat gorge of the Big Muddy was most impressive as an effect of glacial drainage, while the most unusual was the unglaciated triangle from the east. The first warning is the disappearance of Hudson's Bay rocks on the surface. One is used to looking at the morainic knolls and ridges and seeing granite and limestone boulders sometimes perched precariously up the sides, bui looking to the south at the edge of the plateau, angling up from the southeast, one notes a complete absence of such boulders. On the plateau to the south of the Rock Glen channel, all the stones on the summerfallows are Rocky Mountain gravel.

Other years I had found locations in the south where the unbroken soil was filled with Indian worked stone. This summer two such places were encountered along the Swift Current Creek and one, with graves, south of Limerick.

But the most pleasurable surprise came last fall. I had examined five collections of artifacts during the summer, but, not until almost the last trip, did any contain Folsam points. A collection in the Cabri district contained two Folsams.

\section{Relics of the Past}

\section{By M. A. WELSH, Prince Albert}

On July 15, 1953, during a visit to Lac La Ronge, I was privileged to have a talk with Mr. Norman Irwin. Mr. Irwin came to La Ronge in 1904 as a trader for Revions and has remained. He now lives on what was the site of the original Hudson's Bay Post in this area. This post, I am informed, was closed in 1830. Mrr. Irwin has turned up several interesting things in his garden, over the last thirty years.

He found a roll of birch bark which when opened up was found to contain a number of sterling silver rings and several sterling silver crosses suspended from a fine silyer chain. Time has not been too kind to these alticles. The rings have become unsoldered; the chains have disinte- grated and most of the crosses have broken. No doubt some squaw placed these in safekeeping, never to return to reclaim them.

$\mathrm{He}$ has also a steel spade head, no doubt discarded as it was no longer serviceable. This spade head bears an imprint "LONDON" on one side and on the other some illegible legend.

The spade head was made from two flat pieces of steel, hammer-welded together to make the bit, but the two separated at the top to form a ferrule for the handle.

He also has several of the old copper kettles and several parts of flintlock rifles. These items enumerated are mostly of a class which we prefer to call trade goods. From their nature I would assume that they date around 1800 . 